\title{
Adventure and the Failure of Love in the City of White Musicians and Moll Flanders
}

\author{
Ranji Shorsh Rauf Muhamad, Bestun Arif Aziz
}

Assistant lectures at university of Sulaimani, Iraq

\begin{abstract}
This paper is about adventure and the failure of love in The City of White Musicians and Moll Flanders. The concept of adventure and the failure love might be discussed separately in many studies but they are hardly ever mentioned together in two different novels. This paper is a comparative study of two novels. The City of White Musicians which is written by a Kurdish novelist Bakhtiar Ali and Moll Flanders which is written by Daniel Defoe.

The study focuses on the theme of adventure and the failure of love in both novels and the reasons which lead the main characters in these novels to make adventure for the sake of love and get married; moreover it sheds light on how the society treats with them. The purpose of this study is that to illustrate the factors which lead the Kurdish lady to make adventure for her failure love and the young English girl make adventure to have a stable life.
\end{abstract}

Keywords: The City of White Musicians, Moll Flanders, Adventure, the failure of love

\section{Adventure AND the FAILURe OF Love in The City of White Musicians}

In fact there are three important topics that can be taken into consideration in art and literature which are sex, religion and politics. Throughout history these mentioned topics are significant and not only concerned and involved by the artists and writers but paid attention by all the people.

The titles of love, failure and adventure for the sake of love are part of these important topics. In this novel Dalia Sirajadeen goes through a severe and tough experience of love with somehow illusionary character called Basm Algerian.

As a matter of fact before starting the novel, Basm is captured by Saddam Hussein`s regime; therefore every now and then his ghost appears in Dalia`s mind. So it means that she has to devote all her life for her love and make adventures for the sake of love because her lover physically does not exist with her, she decides to sacrifice everything just to see him again. One might ask that does her lover deserve all these victimizations, according to some critics man only once fall in love madly in his life and will do everything for the sake of it. The same thing is true for Dalia, she tries day and night just to get news from Basm yet she thinks that she hasn't done anything.

I am always saying that if you lose your first love, you will be a loser creature forever. Love is not like a chess game when you lose it, try again and train to learn and think about a next game. In love the case is not like that, there is only one game when you lose it, it means that you are a loser forever. No one on this planet will fall in love twice with the same feeling, emotion and madness. \{Ali: 156-157\}

All her physical and spiritual love are nothing just to receive some information about Basm Algerian; therefore, the first love is great, it needs a great victimization.

In this novel, Dalia Sirajadeen failed in her love particularly when Basm is imprisoned and transferred to unknown place by General Intelligent Agency of Iraqi regime. From now on Dalia looks everywhere for her lover and tries very hard to find him, but it is useless. She cannot reach those places where she suspects that Basm has been captured in. She has to make adventure in order to reach the unknown places, that is why she is obliged to make risk with her spirit and body to gain her object. She knows that she has nothing in her life: no properties, no family, and no money. The only thing she does have is her physical beauty and her womanish body; moreover, opening the iron door 
of the dictator regime`s prison need the woman`s body because the security guards and the state men are thirsty to sex and cannot bear the beauty of the lady.

She realized that, only the woman`s body is able to bend the knee of severe and stone hearted men of this regime. They are slave of their instinct and the only thing which connect them with human beings is not their heart, reason, or imagination but it is their male sexual organ which is like upside down candle and always burning in their pants. Dalia was not prostitute she wanted to be a translator in one of the translation bureau, she wished became a novelist and narrate her life or became an English teacher and teaches English in her childhood city in Kurdistan. \{Ali: 241\}

It is worth mentioning that Dalia and Basm are not responsible for the failure of their love, it is out of their willpowers besides this causes adventurous behaviour of Dalia. The failure of her love leads her to go to tens and hundreds of secret and dangerous places of government in spite of that becomes familiar with thousands of dead, killing and torturing stories of innocent people and see many hidden and unknown places.

In her journey she saw all the secret places and angles of this dictator regime which governed the country. She had reached the dark prisons and the unknown places; however, every time she thought that it is the last prison, she saw many other deeper and darker prisons. She did not know the ending point of these torturing rooms, prisons and cemeteries. The kingdom of death became deeper and darker as far as she went. $\{$ Ali: 240$\}$

Although Dalia`s adventure is useless, she is not hopeless and never loses her strength. Every time she tries harder and spends more efforts. "Dalia felt that she got a great secret about the function of these huge instruments and learnt about them; however, she never found that way which led her to Basm." \{Ibid\} it means that all her adventures she makes is due to her failure in love thus it is forceful rather than willingful.

In fact Dalia devotes all her life for searching of Basm. She wants to find him with any value. It might be remarked that self-sacrifice for the sake of love is a sacred goal that is why the victimizer acts less concern for herself than for love. She is a good example for this kind of love. She is ready to sacrifice everything for the sake of love. It is not clear that whether love itself is so sacred or the lover, whether Dalia does everything for the sake of love or for the person called Basm Algerian.

As it is mentioned before, the adventure of Dalia is due to her failure in love. She is ready to everything physically and spiritually for the sake of that love. She wants to show that she is faithful toward the mission of love. She always repeats that, looking for Basm does not mean that to find him and get married with, but only she aims that to be sure he is alive and they live under one sky. She knows very well that, she can no longer purely love each other because she is now just a prostitute nothing more. As she said in a dialogue with his spirit:

Do I ask you anything? I did not say that when you have been released from prison marry me. I did not say that, you should get married with immoral prostitute of the brothel. If you think so, you are wrong. I only want to know that you are alive on this planet. I am sure you are alive, do not say I am dead, when I die, I will believe in your death until you breathe, I will alive if you die, I will die too. \{Ali: 151$\}$

It means that, all the adventures she makes is for the sake of her spiritual love, she wants to be truthful toward her love. It is not for the sake of one person; moreover, she does not do that for her own interest and get a reward from any one. She does that just because she believes in such kinds of love.

In fact, the behaviour, activity and dialogue of Dalia in this novel lead the reader to see that Dalia wants in a wrong way get the right object. Through losing her virginity and humanity she wants to reach the top of her love which is to see her lover again. She aims to achieve spiritual love through her body and via her adventure gets knowledge. When she looks at herself she thinks that she is just a prostitute nothing more. Forcefully she becomes a prostitute for the sake of love not willingly. She remains as a prostitute until she finds Basm or at least get a news from him. She does not blame herself because she believes that to be a prostitute for a holy goal is a sacred thing. for instance when 
she asks an officer who is responsible for the cases of all the killed people by regime to allow her to look for Basm`s file among all the files of the murdered people, in return he asks her to have an affair with. "Every night the officer comes quietly for an hour among the dusty files sleeps with her and nakedly runs her among the old lockers". \{Ali: 222-223\}

It might be noticed that, she sleeps with the officers and commanders just to get some information about Basm. Now she believes that the result of all her adventures is just failure and she is recording failure and failure. She wants to gain her true love but she realized that, she pays too much for it; moreover, there is no love as before and the lover is absent, what is she doing now is useless and behaving as a prostitute is aimless. She cannot look at herself as the pure and virgin lady as the first time she falls in love. Everything changes: there is no Basm, no love, and no virgin Dalia. When she finds Basm`s file among the cases of the dead people and knows that he is not alive anymore. She promises herself not to have affair with any man in her life and she will not act as a prostitute anymore.

Dalia quietly picks Basm`s file up then turn the first page over: with a beautiful handwriting is written ( The Criminal Basm Walid Subhi Algerian) she looks at all the pages of the file in the last page written he is sentenced to death and the concern people must accomplish it. She calmly puts the file in a private place. She washes her face and with all her efforts try to keep her tears then she takes out her make up from her purse and use it. She goes upstairs and passes through along corridor. It is very hot outside then she enters the officer room and puts the file on the desk after that she turns off the curtain, in front of the yellow lamp she sleeps with the last man for the last time in her life. \{Ali: 227$\}$

Dalia Sirajadin tries physically, spiritually and psychologically to see Basm Algerian again. He uses all immoral and moral ways to achieve a sacred love. According to macvillian human beings can use all the good and bad ways to get their goal but to achieve love in a wrong way is somehow difficult because love itself is pure and spiritual.

When love is failed, the lover and beloved will make all adventures to correct the failure as one can see that in Dalia`s behaviour who tries all ways. Thus adventure is the result of failure.

\section{AdVenture AND THE FAILURe OF LOVE IN MOLL Flanders}

The novel, Moll Flanders is a picaresque novel. It is a story of a character from her birth till her old age. She is a daughter of a lady who stole something during her pregnancy. Moll's mother was not executed because she was pregnant with Moll instead she was exiled to Virginia. Even Mollss birth place was abnormal, she was born in new gate prison, her birth place became a shadow over her entire life. This story tells the reader even before Moll was born her life had already started with adventure. Her mother's thievery shifted her whole life, she lives in England motherless. Her whole life started with adventure when she was three or four years old, she joined the band of gypsies. From the early of her life she tells the Matron that she does not want to become a servant in any household but that it is her ambition to become a gentlewoman. Surely the events in this novel are based on the writer's observation of the real life of many children at his time and his close study of the conditions of them. (Lall: 101)

Moll's life has been changed when she is taken to live with the rich family at the age of fourteen. This family has two daughters and two sons. There Moll continues until the age of eighteen. During this period she has been sharing the education of the daughters of the family, having learnt how to speak French and how to sing. In spite of that she has become grown up to be an extremely beautiful girl, much more attractive than the daughters of the family. It can be said that to be gorgeous does not bring happiness every time to the people for instance, the elder son of the family, with whom Moll is living feels attracted by her beauty and charm. He tells Moll privately that he has fallen in love with her and would marry her, this is regarded as the first love of Moll. The lover seems very impatient because after saying "I love you" directly started embracing and kissing her. Before leaving her, he gives her some money one may see that from the first scene of this couple, the behaviour of the elder brother is more like the seduction rather than love. Suddenly kissing and leaving some money are not the characteristics of true love; however, his love-making has certainly pleased her because he is a handsome young man and his gift of money has added to her pleasure. Whenever he gets opportunity, he kissed her and embraces her without being observed by any member of the family. (David: 77) 
Moll has fallen truly in love with him; she does not know he only plays with her. One day he gives her a silk purse and one hundred guineas. When she sees the silk purse her colour went and came at the sight of the purse. She could not say any words and she makes no resistance and let him do just what he pleases him, so he seduces her and she loses her virginity. Here she must be blamed; she loves money as much as him. She is very materialist, losing her virginity for the sake of money. This relationship continue for about six months then the young brother tells the family that he had fallen in love with Moll and wants to marry her. The elder son thinks that it is a good chance to escape from his commitment to Moll. He encourages Moll to accept his younger brother`s proposal. Moll feels deeply depressed by her lover's request to marry his younger brother because she is actually in love with the elder brother. This is the first failure of love of Moll and she becomes ill when she is obliged by the elder brother to get married with his young brother. She is now confused the whore of one brother and the wife of another.

I was now in a dreadful condition indeed, and now I repented heartily my easiness with the eldest brother; not from any reflection of conscience, for I was a stranger to those things, but I could not think of being a whore to one brother and a wife to the other. It came also into my thoughts that the first brother had promised to make me his wife when he came to his estate; but I presently remembered what I had often thought of: that he had never spoken a word of having me for a wife after he had conquered me for a mistress; and indeed till now, though I said I thought of it often, yet it gave no disturbance at all, for as he did not seem in the least to lessen his affection to me. \{Defoe: 29$30\}$

In fact it is a great adventure for Moll to get married with a man while she lost her virginity with another man. The elder brother deceived his young brother by getting him drunk at the night of the wedding in order not to suspect Moll about losing of her virginity. Moll is a victim here because she loves someone but gets married with someone else. Even when she marries to the younger son, she continues to imagine that she is having sex with her former lover; and that is why she says that she commits adultery and incest every night in her desire if not in actual fact. Moll spends five years with this husband after which he dies. During this time she gives birth to two children and they were taken by the parents of her deceased husband.

It is worth mentioning that after the death of her first husband Moll gets married several times. Moll does not have any one in this world. She is father and mother less that is why she is always searching for someone to be a back for her and support her. She has to go through some adventures and tries some bitter experiences to find someone to care about her.(Gerard:63)

Moll gets remarried with a linen-draper who is not exactly a gentleman, her choice for this man proves to be a wrong one, because he spends all his money in two years. He is extravagant one, and unable to repay his debts therefore; he escapes to France. Moll becomes a widow for the second time she failed with this marriage again. One might notice that at that time people care too much about money in the marriage process. They wanted to married with the wealthy one, physical appearance is not so important but for sexual pleasure and for a couple of days they look for beautiful and charming lady. (Lall:111)

Moll gets married for the third time with a captain of the ship came from Virginia. She makes adventures and goes with him to Virginia. She spends some years happily with him but their happiness does not continue for a long time, when she realizes that she got married with her own half brother, she feels deeply distressed by the thought that she has been leading a life of incest and whoredom under the appearance of an honest wife. It can be said that fate has a great role in failing the third marriage of Moll. (Lall:112)

It is difficult for Moll to live alone, she looks for a job, she finds a gentleman who has an insane wife. She works for this gentleman and takes care of his insane wife in return gets an amount of money. She lives in the same house with them and falls in loves with the gentleman. She has sexual relation with the men out of marriage for about six months and she becomes pregnant and gives a birth for a child. One might remark that it is a great adventure has sexual relationship out of marriage because it is not allowed morally, socially, traditionally and religiously. As usual Moll failed in this love relationship because her lover now feeling repentant of his extra marital relationship with Moll decided to 
terminate the relationship. He writes a letter to Moll informing her of his decision and also informing her that he would take charge of the child of their illicit union and would bring him up at his own expense. Moll once again finds herself alone and friendless in life. (Douglas: 46 )

As a matter of fact Moll cannot live without husband. She has a contact with a bank official; he is a married man with a wife and no wife at the same time because his wife has a series of lover one after another. It means that he is legally has a wife but physically she is with someone else. He asks Moll`s hand for the marriage. She responded that he has to divorce his wife first then propose marriage to her. During this time Moll meets another man from the Lancashire, he looks rich and asks Moll's hand she directly agrees to get married with while she promises the bank official. This tells the reader Moll does not want to waste the time. She is just like the machine because she makes money with her marriages and produces children at the same time. She gives birth to another child with this marriage and the husband tells Moll and he will go to Ireland and tries his luck there. It means that she failed in this marriage again. Moll makes adventure to get married with a man while she is promising another one because soon after that the bank official appears with his divorce paper. Moll gets married with him she lives happily with her new husband, for a period of five years during which she gave birth to two children. (Lall: 114)

I turned from him, for it filled my eyes with tears too, and asked him leave to retire a little to my chamber. If I had a grain of true repentance for an abominable life of twenty four years past, it was then. "oh, what a felicity is it to mankind," said I to myself, " that they cannot see into the hearts of one another! How happy had it been if I had been wife to a man of so much honesty and so much affection from the beginning. (Defoe: 159)

Moll for a while thinks about her twenty four years past life, she blames her fate and she says how happy has it been if she has been wife of a man of so much honesty and affection from the beginning of her life. This speech of Moll gives an indication to the reader that she has not purposely changed her husband's but forcedly she gets married five times. It can be noticed that she pities her current husband because she does not have a pure past she had several sexual relationship with other people that is why she says this poor man divorced a whore and married another whore. After five years unfortunately her husband dies suddenly and Moll`s happiness ends with this good man. Moll is very sad now because she is forty eight years old and it is difficult to find another husband.

When Moll is disappointed to find another man, she decides to try a new adventure. She becomes a thief, and steals things from the shops such as silver mug, silver spoon, silk handkerchief; moreover, one day she steals the gold necklace from a pretty little girl who returns home from her lessons at a dancing school. As a matter of fact it is poverty which has driven her to commit the first crime, but loving for money addicts her to continue on this bad habit.()

She humoured the thing so well that nobody suspected her, and I was got home a full hour before her. This was my first adventure in company. The watch was indeed a very fine one and had many trinkets about it, and my governess allowed us 20 pounds for it, of which I had half. And thus I was entered a complete thief, hardened to a pitch above all the reflections of conscience or modesty, and to a degree which I never thought possible in me. Thus the devil, who began by the help of an irresistible poverty to push me into this wickedness, brought me on to a height beyond the common rate, even when my necessities were not so terrifying; for I had now got into a little vein of work, and as I was not at a loss to handle my needle, it was very probable I might have got bread honestly enough.(177 )

Through the analysis of this quotation one might notice that Moll has inherited much of her evil nature from her mother. At one point in the novel it is mentioned that Moll's mother had been both a whore and a thief in her younger days and Moll herself becomes a whore and a thief in the course of her life. So her sensuality and thefts are somehow a consequence of this natural propensity; however, the condition she lives in has a great role in moulding her character and leading her on wrong paths and fate also had a great impact on her life at the beginning of this novel moll said "if we had orphan house in England I would not have fallen into wrong hands" (Defoe:10) 


\section{CONCLuSions}

Throughout this study one can notice that both Moll and Dalia are victims of something out of their hands: Moll is a victim of a bad system, mother and society. Dalia is also a victim of tradition and culture in spite of that she is one of the victims of Saddam Hussein`s regime. It is worth mentioning that they are suffering twice, once because they are women, and once due to the bad system.

As a result of the paper, one can see that persecution lead to the adventure and revenge. No one can bear the oppression forever as can be remarked in these two novels.

\section{REFERENCES}

Ali, Bakhtiar. The City of White Musician, Ranj Printing House, Sulaimania, 2005.

Blewett, David. "Changing Attitudes Toward Marriage in the Time of Defoe: The Case of Moll Flanders" Huntington Library Quarterly 44, 1981.

Defoe, Daniel. Moll Flanders, York Press, Lebanon, 2008.

Howson, Gerard. “who was Moll Flanders?” The Time Literary supplement (January 18, 1968)

Lall, Ramji. Moll Flanders A Critical Study Educational publisher, New Delhi, 2010.

\section{AUTHORS' BIOGRAPHY}

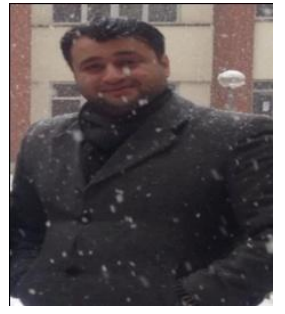

Ranji Shorsh Rauf Muhamad, was born in Sulaimani / Iraq. I graduated in 2008 at university of Sulaimani I have B.A degree in English Language and Literature. I was third among one hundred students. I got my M.A degree in modern English novel in 2013 at university of Sulaimani. Now I am assistant lecturer at the same university and teach English Novel.

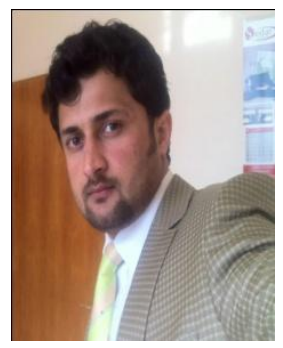

Bestun Arif Aziz, was born in Sulaimani / Iraq. He graduated in 2009 at university of Sulaimani and he has B.A degree in Kurdish Language and literature. he got his M.A degree in Kurdish Novel in 2014 at university of Sulaimani. Now he is assistant lecturer at college of basic education in Sulaimani. 